\title{
Effect of honey supplementation on Egyptian buffalo semen
}

\author{
Mohamed Mahmoud Moustafa kandiel ${ }^{1}$, Ahmed Reda Mohamed Elkhawagah
}

Theriogenology Department, Faculty of Veterinary Medicine, Benha University, Benha, Egypt.

\begin{abstract}
This study testified the effect of honey supplementation $(0.5-4.0 \%)$ in milk on the quality of chilled and frozen buffalo spermatozoa. Semen was chilled with/without honey and examined for motility, viability, plasma membranes integrity by hypo-osmotic swelling test (HOS) at $0,1,2$ and $4 \mathrm{~h}$. Frozen-thawed semen was examined for the same criteria beside the viability index and in vitro cleavage rate. The motility, livability and HOS of chilled semen upsurge with honey supplementation $1.0-2.0 \%$. The normality of chilled spermatozoa was improved in the presence of $2.0-4.0 \%$ of honey at $4 \mathrm{~h}$. Tail abnormalities decreased with milkhoney $0.5,1.0$ and $2.0 \%$ at 2,1 and $4 \mathrm{~h}$, respectively. Incorporation of honey in milk extenders at levels of $0.5-2.0 \%$ was associated with an enhanced postequilibration motility. The post-thawing motility showed a steady increase with honey levels. The viability index increased $(\mathrm{P}<0.001)$ with milk-honey $2.0 \%(109.00 \pm 9.91)$ and $4.0 \%(112.00 \pm 14.41)$. In vitro cleavage rate was clearly $(\mathrm{P}$ 0.001) enhanced in the co-existence of milk-honey $2.0 \%$ compared with control (74.00 vs. 45.83). In the meantime, a reasonable high cleavage rate $(67.00 \%)$ was encountered with milkhoney $0.5 \%$. In conclusion, incorporation of honey in skim milk extenders is promising to enhance the characteristics and fertilizing potential of stored buffalo's semen due to its nutritive and protective properties.
\end{abstract}

Keywords: buffalo, chilled semen, frozen semen, honey, in vitro fertilization, skimmed milk, spermatozoa.

\section{Introduction}

A suitable diluent is a fundamental need for the effective conservation of spermatozoa and for acquiring higher conception rates in field trials utilizing extended semen. Several extenders have been developed to preserve bovines' spermatozoa for long-term storage. It has been reported that extenders can act as an energy source for sperm metabolic maintenance, provide $\mathrm{pH}$ buffering from sperm cell waste, ions for membrane and cell stability, and antibiotics to prevent growth of microbes that can cause diseases (Gadea, 2003). Storage of spermatozoa in liquid state decreases the available energy sources for spermatozoa, and accordingly influences its proper functioning (Akhter, 2006).

Honey encompasses about 200 components, with the foremost elements are sugars, which include fructose $(\sim 38.5 \%)$, glucose $(\sim 31.0 \%)$, maltose $(\sim 7.1 \%)$, and other complex carbohydrates (Silva et al., 2016).
Honey addition to egg yolk was found to improve spermatozoa motility and viability of goat chilled semen (Olayemi et al., 2011). The supplementation of honey to tris-extender was noticed to enhance sperm motility of chilled and frozen cattle bull semen and also increase the conception rate (El-Sheshtawy et al., 2014).

Milk and milk-based extenders are famous for its practicality and efficiency in protecting spermatozoa of many species (Batellier et al., 2001). Skim milk extender has been known as a suitable storage medium for chilled buffalo bull semen due to its higher ability to preserve semen quality, availability and economic suitability (Akhter, 2006).

The present study was designed to evaluate the effect of honey implementation in skim milk extender, as a source of sugar, on the characteristics of buffalo semen preserved at $4^{\circ} \mathrm{C}$ (chilled) or at $-196^{\circ} \mathrm{C}$ (frozen).

\section{Materials and Methods}

\section{Semen collection and evaluation}

Three proven fertile Egyptian buffalo bulls of an age $4.5 \pm 1.5$ years maintained at Teaching Farm, Faculty of Veterinary Medicine, Moshtohor, Qalyubia Governorate, Egypt, were used in the current study. Semen samples were collected with an artificial vagina maintained at $42-45^{\circ} \mathrm{C}$, for a period of 14 weeks. Two ejaculates were collected per one time weekly. Semen was held for $10 \mathrm{~min}$ at $37^{\circ} \mathrm{C}$ in the water bath before being evaluated and extended. Sperm activity was assessed microscopically at 100X (Mass motility) and 400X (Individual motility). Sperm concentration was measured with Neubauer haemocytometer. Good quality semen samples (i.e. motility, livability and normality $\geq 70-75 \%$ and conc. $\geq 800 \times 10^{6} / \mathrm{ml}$ ) from 3 bulls were pooled, to minimize the individual variability and to attain adequate semen for triplicates, and were split into aliquots each of $0.5 \mathrm{ml}$ for further processing.

\section{Semen processing}

Milk-Honey extenders were prepared by adding 0 (control), 0.5, 1.0, 2.0 and $4.0 \mathrm{ml}$ of honey (Clover flower nectar, ISIS For Food Industries Co., Cairo, Egypt ) per $100 \mathrm{ml}$ milk extender that was prepared with powdered skimmed milk $\left(\mathrm{SKIMZ}^{\circledR}\right.$; CANDIA) $10 \%$ (weight/volume) heated at $92-95^{\circ} \mathrm{C}$ for 10 min before being used for semen extension. Antibiotics (Gentamycin sulphate, $500 \mu \mathrm{g} / \mathrm{ml}$ ) were added to all extenders at room temperature.

Chilled semen processing: Semen aliquots were diluted with milk-honey extenders in triplicates to 
yield an approximate concentration of $50.0 \pm 5.0 \times 10^{6}$ sperm $/ \mathrm{ml}$. The extended semen was cooled from 37 to $4^{\circ} \mathrm{C}$ in $2 \mathrm{~h}$ and stored at $4^{\circ} \mathrm{C}$ for $4 \mathrm{~h}$. All the semen quality analyses were accomplished at $0,1,2$ and $4 \mathrm{~h}$ post-cooling. The experiment was repeated for seven consecutive weeks.

Frozen semen processing: Pooled semen sample was extended with milk-honey extenders in order to provide nearly $50.0 \pm 5.0 \times 10^{6} \mathrm{sperms} / \mathrm{ml}$. Extended semen was slowly cooled (approximately for $2 \mathrm{~h}$ ) to $4^{\circ} \mathrm{C}$ and was packed into $0.5 \mathrm{ml}$ polyvinyl straws (Minitub, Germany) equilibrated for $2 \mathrm{~h}$. After equilibration, straws were racked horizontally in a vapor $(5.5 \mathrm{~cm}$ above liquid nitrogen, $\mathrm{N}_{2}$ ) for $10 \mathrm{~min}$. prior to dipping and storage in a $\mathrm{N}_{2}$ tank until thawing. After $24 \mathrm{~h}$, straws $(\mathrm{n}=4$ /group each time) were thawed at $\sim 38^{\circ} \mathrm{C}$ for $30 \mathrm{sec}$ and motility estimations were done at hourly intervals for a period of $3 \mathrm{~h}$ post-thawing, while they were held in incubator at $\sim 38^{\circ} \mathrm{C}$. Viability index was calculated according to the following formula conveyed by Milovanov (1962 cited by Amer et al., 2008). Absolute index of viability $=\sum$ $a_{1} t_{1}+a_{2} t_{2}+\ldots \ldots+a_{n} t_{n}$, where $a_{1}, a_{2} \ldots a_{n}$, are the subsequent rate of motility. $t_{1}, t_{2} \ldots t_{n}$, are the successive periods at which the corresponding motility scores are recorded. $\mathrm{t}$ - Value (time index) was calculated by the formula: $\mathrm{t}=\mathrm{T}_{\mathrm{n}+1}-\mathrm{T}_{\mathrm{n}-1} / 2$, where: $\mathrm{T}_{\mathrm{n}+1}=$ Time from beginning of the trial till examination next to the given and $\mathrm{T}_{\mathrm{n}-1}=$ Time from beginning of the trial till examination previous to the given. The formula of first observation was $\mathrm{L}_{1}=\mathrm{T}_{2} / 2$. The formula of last observation was $t_{x}=T_{x}-T_{x-1} / 2$. Experimental trials were conducted for seven consecutive weeks.

\section{Semen quality assays}

Progressive sperm motility was assessed at 400X magnification as described earlier. Slides for sperm viability and morphology were stained with Eosin-Nigrosin and examined microscopically at $1000 \mathrm{X}$ magnification according to Chenoweth (2002). Morphological abnormalities were described according to Yimer et al. (2015), where spermatozoa ( $\mathrm{n}=$ 200/slide) were assessed for defects in head (detached, tapered, giant and micro head) and tail (cytoplasmic droplets, bent mid-piece, irregular mid-piece, broken tail, bent tail, coiled tail and looped tail) regions. Hypoosmotic swelling test (HOS) was used to demark sperm plasma membrane integrity. The HOS solution (osmotic pressure $\sim 190 \mathrm{mOsm} / \mathrm{kg}$ ) was prepared from sodium citrate (Merck KGaA, Germany) $0.735 \mathrm{~g}$ and fructose (Merck KGaA, Germany) $1.351 \mathrm{~g}$ dispensed in $100 \mathrm{ml}$ distilled water. To perform assay, semen sample (100 $\mu \mathrm{l})$ was mixed with pre-warmed HOS solution $(900 \mu \mathrm{l})$ and incubated at $37^{\circ} \mathrm{C}$ for $60 \mathrm{~min}$. Swollen and/or curled tails signified an intact plasma membrane, and accordingly the percentage of HOS positive sperms was calculated (Akhter et al., 2008).

\section{Assessment of in vitro fertilizing capacity of semen}

Ovaries were collected from buffalo (Bubalus bubalis) within $2 \mathrm{~h}$ post-slaughter at local abattoir (Qalyub, Qalyubia, Egypt) and transported to the laboratory in normal saline $(0.9 \% \mathrm{NaCl})$ supplemented with antibiotic $(100 \mu \mathrm{g} / \mathrm{ml}$ streptomycin sulfate and 100 $\mathrm{IU} / \mathrm{ml}$ penicillin) sustained at $\sim 35^{\circ} \mathrm{C}$. Oocytes were harvested from $2-5 \mathrm{~mm}$ antral follicles with $20 \mathrm{G}$ needle into PBS with $3 \%$ bovine serum albumin fraction $\mathrm{V}$ (Sigma-Aldrich offers Aldrich, Cat No. 10735078001) and gentamycin sulphate $(50 \mu \mathrm{g} / \mathrm{ml})$. Oocytes with intact layers of cumulus cells and homogenous cytoplasm were selected (Warriach and Chohan, 2004) for in vitro maturation as described by Mahmoud (2001). Thawed frozen semen ( $n=4$ /group) from the experimental groups was capacitated using BO medium (Brackett and Oliphant, 1975) supplemented with $20 \mu \mathrm{g} / \mathrm{ml}$ heparin plus $3.383 \mathrm{mg} / \mathrm{ml}$ caffeine (Niwa and Ohgoda, 1988). Matured oocytes were co-cultured with capacitated sperms (1-2 $\times$ $10^{6}$ sperms $/ \mathrm{ml}$ ) according to Iritani and Niwa (1977) and incubated at $38.5^{\circ} \mathrm{C}$ under $5 \% \mathrm{CO}_{2}$ in humidified air for $6 \mathrm{~h}$. Fertilized oocytes were transferred to in vitro culture droplets for further development inside $\mathrm{CO}_{2}$ incubator (Aoyagi et al., 1990) and the early cleavage divisions (8-16 cell embryo) were examined every 24 for $72 \mathrm{~h}$. Accordingly, the cleavage rate was calculated according to Iritani et al. (1984). In vitro fertilization experimental trials were conducted in quadruplicates.

\section{Statistical analysis}

The average of each triplicate set of each extender per each week was calculated, then the data of semen quality parameters (presented as Mean \pm SEM, $n$ $=7$ weeks) were analyzed with One Way Analysis of Variance (ANOVA) using SPSS (Ver. 16). Multiple comparisons of the means were done with LSD test. Chi-square test was used to compare the fertilization (cleavage) rate amongst different groups (Bang and Davidian, 2010). P value was set at $<0.05$ to define statistical significance.

\section{Results}

Effect of honey supplementation in buffalo bull extenders on chilled semen characteristics

\section{Motility}

The motility of buffalo bulls' spermatozoa extended with milk based was significantly different after honey supplementation. Such eminent changes were evident at $1 \mathrm{hr}$ and thereafter $(\mathrm{P}<0.001)$. At $0 \mathrm{~h}$ honey supplementation at 1.0 and $2.0 \%$ was associated with the upsurge of motility rates. At 1,2 and $4 \mathrm{~h}$ postchilling, addition of honey at $2 \%$ was associated with the highest motility rate (Table 1 ).

\section{Livability}

The livability of extended buffalo spermatozoa did not differ significantly at 0,1 and $2 \mathrm{~h}$, but varied significantly $(\mathrm{P}<0.05)$ at $4 \mathrm{~h}$ post-cooling (Table 1$)$. At $1 \mathrm{~h}$, spermatozoa livability was higher with milk-honey $0.5 \%$. At 2 and $4 \mathrm{~h}$, milk based extenders improved the livability, with higher value were observed with milkhoney $1.0 \%$. 
Table 1. Influence of incorporation of honey in extenders on the characteristics of chilled buffalo semen.

\begin{tabular}{|c|c|c|c|c|c|c|c|}
\hline Semen parameter & Time (h) & Milk control & Milk-honey $0.5 \%$ & Milk-honey $1.0 \%$ & Milk-honey $2.0 \%$ & Milk-honey $4.0 \%$ & Sig. \\
\hline \multirow[t]{4}{*}{ Motility } & 0 & $67.00 \pm 4.29$ & $67.00 \pm 4.67$ & $72.00 \pm 3.09$ & $71.00 \pm 2.21$ & $62.50 \pm 3.13$ & $\mathrm{~ns}$ \\
\hline & 1 & $58.00 \pm 1.33^{\mathrm{a}}$ & $58.00 \pm 1.70^{\mathrm{a}}$ & $65.00 \pm 1.49^{b}$ & $72.00 \pm 0.82^{c}$ & $57.00 \pm 4.42^{\mathrm{a}}$ & $* * *$ \\
\hline & 2 & $53.00 \pm 3.09^{\mathrm{a}}$ & $57.00 \pm 3.27^{\mathrm{a}}$ & $53.00 \pm 3.59^{\mathrm{a}}$ & $68.00 \pm 0.82^{\mathrm{b}}$ & $60.00 \pm 1.83^{\mathrm{a}}$ & $* * *$ \\
\hline & 4 & $58.00 \pm 2.26^{\mathrm{a}}$ & $57.00 \pm 1.70^{\mathrm{a}}$ & $58.00 \pm 2.26^{\mathrm{a}}$ & $66.00 \pm 1.25^{\mathrm{b}}$ & $62.50 \pm 3.41^{\mathrm{ab}}$ & $* * *$ \\
\hline \multirow[t]{4}{*}{ Livability } & 0 & $84.20 \pm 1.98$ & $87.78 \pm 2.50$ & $85.33 \pm 3.48$ & $90.30 \pm 1.44$ & $86.80 \pm 3.46$ & ns \\
\hline & 1 & $80.60 \pm 2.34$ & $85.30 \pm 2.11$ & $82.80 \pm 2.97$ & $82.70 \pm 3.12$ & $79.60 \pm 3.85$ & ns \\
\hline & 2 & $83.00 \pm 2.74$ & $81.90 \pm 3.19$ & $85.00 \pm 2.96$ & $83.80 \pm 2.15$ & $81.88 \pm 3.18$ & ns \\
\hline & 4 & $76.70 \pm 3.00^{\mathrm{a}}$ & $83.40 \pm 2.27^{\mathrm{ab}}$ & $84.80 \pm 2.52^{b}$ & $82.78 \pm 2.23^{\mathrm{a}}$ & $76.30 \pm 3.73^{\mathrm{a}}$ & $*$ \\
\hline \multirow[t]{4}{*}{ Normality } & 0 & $79.90 \pm 3.94$ & $78.00 \pm 2.65$ & $79.22 \pm 2.76$ & $80.50 \pm 3.02$ & $79.20 \pm 3.03$ & ns \\
\hline & 1 & $84.10 \pm 3.52$ & $81.40 \pm 3.69$ & $84.00 \pm 2.80$ & $84.10 \pm 3.66$ & $82.70 \pm 3.08$ & ns \\
\hline & 2 & $76.70 \pm 4.31$ & $82.20 \pm 3.15$ & $81.60 \pm 2.38$ & $81.40 \pm 4.06$ & $76.40 \pm 5.21$ & ns \\
\hline & 4 & $84.40 \pm 2.52^{\mathrm{ab}}$ & $77.80 \pm 3.15^{\mathrm{a}}$ & $80.13 \pm 3.98^{\mathrm{ab}}$ & $88.00 \pm 1.67^{b}$ & $85.11 \pm 2.93^{\mathrm{ab}}$ & $*$ \\
\hline \multirow[t]{4}{*}{ Tail abnormality } & 0 & $19.20 \pm 3.88$ & $20.33 \pm 2.48$ & $19.56 \pm 2.62$ & $18.70 \pm 2.76$ & $20.50 \pm 2.69$ & ns \\
\hline & 1 & $15.50 \pm 3.41$ & $17.70 \pm 3.51$ & $14.80 \pm 2.39$ & $15.20 \pm 3.39$ & $17.50 \pm 2.88$ & ns \\
\hline & 2 & $26.50 \pm 4.04^{\mathrm{a}}$ & $15.33 \pm 2.80^{b}$ & $20.13 \pm 1.33^{\mathrm{ab}}$ & $21.67 \pm 2.69^{\mathrm{ab}}$ & $17.67 \pm 3.79^{\mathrm{ab}}$ & $* *$ \\
\hline & 4 & $17.50 \pm 2.54^{\mathrm{ab}}$ & $22.11 \pm 3.00^{\mathrm{a}}$ & $19.25 \pm 4.12^{\mathrm{ab}}$ & $11.75 \pm 1.64^{\mathrm{b}}$ & $14.22 \pm 2.89^{\mathrm{b}}$ & $* * *$ \\
\hline \multirow[t]{4}{*}{ Head abnormality } & 0 & $0.90 \pm 0.28$ & $1.44 \pm 0.41$ & $1.10 \pm 0.67$ & $0.70 \pm 0.37$ & $1.10 \pm 0.31$ & ns \\
\hline & 1 & $0.40 \pm 0.22$ & $0.80 \pm 0.33$ & $1.20 \pm 0.51$ & $0.60 \pm 0.27$ & $0.70 \pm 0.33$ & ns \\
\hline & 2 & $0.90 \pm 0.31$ & $0.70 \pm 0.21$ & $1.00 \pm 0.47$ & $0.40 \pm 0.22$ & $0.75 \pm 0.25$ & ns \\
\hline & 4 & $0.40 \pm 0.22$ & $1.50 \pm 0.54$ & $1.40 \pm 0.83$ & $0.30 \pm 0.21$ & $0.90 \pm 0.35$ & ns \\
\hline Membrane integrity & 0 & $84.00 \pm 2.65$ & $87.50 \pm 1.32$ & $81.75 \pm 3.40$ & $82.50 \pm 3.80$ & $76.25 \pm 5.79$ & ns \\
\hline \multirow[t]{3}{*}{$(\mathrm{HOS})$} & 1 & $81.25 \pm 3.20$ & $82.50 \pm 1.26$ & $88.00 \pm 2.16$ & $81.00 \pm 3.11$ & $80.00 \pm 4.16$ & ns \\
\hline & 2 & $82.00 \pm 1.41^{\mathrm{ab}}$ & $75.60 \pm 2.20^{\mathrm{ab}}$ & $83.50 \pm 2.87^{\mathrm{a}}$ & $82.00 \pm 0.82^{\mathrm{ab}}$ & $74.75 \pm 3.35^{\mathrm{b}}$ & $* *$ \\
\hline & 4 & $76.50 \pm 2.06$ & $82.25 \pm 1.75$ & $83.50 \pm 3.86$ & $75.50 \pm 1.85$ & $73.25 \pm 6.14$ & ns \\
\hline
\end{tabular}

Means (SEM) with different superscript letters within the same raw were significantly different at $\mathrm{P}<0.05$. $* * *$ and $* * *$ implied $\mathrm{P}<0.05,<0.01$ and $<0.001$, respectively. ns: indicated non-significant differences. 


\section{Morphology}

Extended buffalo spermatozoa morphology was not significantly different in relation to type of extender or its contents of honey except for $4 \mathrm{~h}$ after chilling $(\mathrm{P}<0.001)$, where normal spermatozoa were higher in extenders supplemented with 2.0 and $4.0 \%$ of honey (Table 1). The rate of tail abnormalities of extended buffalo spermatozoa varied at $2 \mathrm{~h}(\mathrm{P}<0.05)$ and $4 \mathrm{~h}(\mathrm{P}<0.001)$. Tail abnormalities were the lowest with milk-honey $1.0 \%$ at $1 \mathrm{~h}$, milk-honey $0.5 \%$ at $2 \mathrm{~h}$ and milk-honey $2.0 \%$ at $4 \mathrm{~h}$. The abnormality in head was not significantly different regardless the type of extender or the time post cooling.

\section{Plasma membrane integrity}

Intact membrane integrity expressed by hypoosmotic swelling test showed none significant difference at 0,1 and $4 \mathrm{~h}$, but significantly varied at $2 \mathrm{~h}$ post-cooling (Table 1). The highest rate of membrane intactness was observed in extended semen with milkhoney $1.0 \%$ medium at $1 \mathrm{~h}$ post cooling.

Effect of honey supplementation in buffalo bull extenders on frozen semen characteristics

\section{Motility}

Motility of buffalo bull spermatozoa showed the highest rates $(\mathrm{P}<0.05)$ just after the extension in milk control and milk-honey $0.5 \%$. Extended buffalo bulls sperm motility was not statistically significant regardless incorporated honey level, though a numerical difference were obvious. Milk extenders supplemented with honey $(0.5-2.0 \%)$ showed the highest rates of motility. The post-thawing motility at 0,1 and $2 \mathrm{~h}$ showed a steady increase in the motility rate with increasing the honey levels (Table 2). At $3 \mathrm{~h}$ postthawing, sperm motility was maintained higher in milk supplemented with honey $1.0-4.0 \%$ than milk control.

\section{Viability index}

Viability index of post-thawed spermatozoa was significantly $(\mathrm{P}<0.05)$ higher in semen extended with milk honey $2.0 \%(109.00 \pm 9.91)$ and $4.0 \%$ $(112.00 \pm 14.41)$.

\section{Plasma membrane integrity}

Membrane intactness of buffalo bulls spermatozoa did not show significant differences, regardless supplemented honey level in the extenders either post-equilibration or post-thawing, though numerical differences was recorded. Milk-honey 0.5 and $1.0 \%$ showed the highest rates of membrane integrity at post-equilibration and post-thawing conditions, respectively (Table 2 ).

Table 2. Influence of incorporation of honey in extenders on the characteristics of frozen buffalo semen.

\begin{tabular}{|c|c|c|c|c|c|c|}
\hline Semen parameter & Milk control & $\begin{array}{c}\text { Milk-honey } \\
0.5 \% \\
\end{array}$ & $\begin{array}{c}\text { Milk-honey } \\
1.0 \% \\
\end{array}$ & $\begin{array}{c}\text { Milk-honey } \\
2.0 \% \\
\end{array}$ & $\begin{array}{c}\text { Milk-honey } \\
4.0 \% \\
\end{array}$ & $\begin{array}{c}\text { Significanc } \\
\mathrm{e}\end{array}$ \\
\hline $\begin{array}{l}\text { Initial motility before } \\
\text { cooling }\end{array}$ & $86.25 \pm 2.39^{\mathrm{a}}$ & $85.00 \pm 2.04^{\mathrm{a}}$ & $81.25 \pm 4.27^{\mathrm{ac}}$ & $73.75 \pm 2.39^{\mathrm{ab}}$ & $70.00 \pm 4.08^{\mathrm{bc}}$ & $* *$ \\
\hline $\begin{array}{l}\text { Post-equilibration } \\
\text { motility }\end{array}$ & $70.00 \pm 5.77$ & $71.67 \pm 1.67$ & $73.33 \pm 6.67$ & $73.33 \pm 1.67$ & $56.67 \pm 8.82$ & ns \\
\hline $\begin{array}{l}\text { Post-thawing motility - } \\
0 \mathrm{~h}\end{array}$ & $43.75 \pm 2.39^{\mathrm{a}}$ & $42.50 \pm 2.50^{\mathrm{a}}$ & $45.00 \pm 4.56^{\mathrm{ac}}$ & $47.50 \pm 2.50^{\mathrm{ac}}$ & $52.50 \pm 3.23^{\mathrm{bc}}$ & $* *$ \\
\hline $\begin{array}{l}\text { Post-thawing motility - } \\
1 \mathrm{~h}\end{array}$ & $35.00 \pm 6.12^{\mathrm{a}}$ & $37.50 \pm 6.61^{\mathrm{ab}}$ & $45.00 \pm 6.45^{\mathrm{ab}}$ & $47.50 \pm 4.79^{\mathrm{a}}$ & $52.50 \pm 7.77^{\mathrm{b}}$ & $* *$ \\
\hline $\begin{array}{l}\text { Post-thawing motility - } \\
2 \mathrm{~h}\end{array}$ & $15.00 \pm 4.56^{\mathrm{a}}$ & $21.25 \pm 4.27^{\mathrm{ab}}$ & $30.00 \pm 6.12^{\mathrm{ab}}$ & $35.00 \pm 7.07^{\mathrm{b}}$ & $31.25 \pm 8.75^{\mathrm{ab}}$ & $* *$ \\
\hline $\begin{array}{l}\text { Post-thawing motility - } \\
3 \mathrm{~h}\end{array}$ & $3.00 \pm 0.75^{\mathrm{b}}$ & $0.75 \pm 0.75^{\mathrm{b}}$ & $8.75 \pm 2.39^{\mathrm{a}}$ & $5.50 \pm 3.30^{\mathrm{b}}$ & $4.00 \pm 1.00^{\mathrm{b}}$ & $* * *$ \\
\hline Viability index & $71.88 \pm 9.76^{\mathrm{b}}$ & $80.38 \pm 9.47^{\mathrm{bc}}$ & $101.88 \pm 12.93^{\mathrm{ab}}$ & $109.00 \pm 9.91^{\mathrm{ac}}$ & $112.00 \pm 14.41^{\mathrm{a}}$ & $* *$ \\
\hline $\begin{array}{l}\text { Post-equilibration } \\
\text { membrane integrity } \\
\text { (HOS) }\end{array}$ & $66.75 \pm 6.90$ & $78.00 \pm 4.22$ & $81.75 \pm 3.47$ & $79.75 \pm 7.10$ & $77.75 \pm 9.31$ & ns \\
\hline $\begin{array}{l}\text { Post-thawing membrane } \\
\text { integrity (HOS) }\end{array}$ & $73.67 \pm 7.13$ & $78.67 \pm 3.93$ & $75.67 \pm 7.45$ & $80.33 \pm 1.86$ & $74.33 \pm 5.36$ & ns \\
\hline
\end{tabular}

Means (SEM) with different superscript letters within the same raw were significantly different at $\mathrm{P}<0.05 . * * *$ and $* * *$ implied $\mathrm{P}<0.05,<0.01$ and $<0.001$, respectively. ns: indicated non-significant differences.

Effect of honey supplementation in buffalo bull extenders on in vitro fertilizing capacity of frozen thawed semen

The fertilization rate noticeably $(\mathrm{P}<0.001)$ differed between buffalo frozen semen extended with milk-honey extenders (Table 3 ). The rate of cleavage divisions (up to $72 \mathrm{~h}$ ) was higher in all milk-honey extenders as compared with control. Milk-honey $2.0 \%$ was associated with the highest cleavage rate $(74.00 \%)$ among all the tested groups. The cleavage rate was little higher with milk-honey $0.5 \%$ (67.00) than milk-honey 1.0 and $4.0 \%$ (64.28 and $64.95 \%$, respectively). 
Kandiel and Elkhawagah. Milk-honey extender effects on buffalo semen.

Table 3. Impact of honey supplementation in milk extender on in vitro fertilization rate.

\begin{tabular}{lccc}
\hline \multicolumn{1}{c}{ Extender } & No. of oocytes & Fertilized oocytes & Fertilization rate $(\%)$ \\
\hline Milk control & 96 & 44 & 45.83 \\
Milk-honey $0.5 \%$ & 100 & 67 & 67.00 \\
Milk-honey 1.0\% & 98 & 63 & 64.29 \\
Milk-honey 2.0\% & 100 & 74 & 74.00 \\
Milk-honey 4.0\% & 97 & 63 & 64.95 \\
\hline
\end{tabular}

The chi-square statistic is 18.29 . $\mathrm{P}<0.001$.

\section{Discussion}

Variant diluting mediators were used for frozen semen processing purposes (Jerez et al., 2016). The composition of semen extenders relies upon the semen utilization, and storage temperature and period. Mammalian spermatozoa require exogenous substrates for a variety of functions e.g. preserving intracellular energy resources, cell constituents and most notably supporting motility (Salisbury et al,. 1978). Milk (skimmed, homogenized or whole milk) gives phospholipids needed to endorse membrane stabilization at lower temperature and minimize acrosomal membrane activation (Bustamante Filho et al., 2009). Sugars are essential component of the extenders to afford the energy required for sperm glycolysis (Aboagla and Terada, 2003).

The outcomes from the present work evidently showed that the foremost impact of honey in semen extenders was to support the motility of chilled buffalo spermatozoa. Honey incorporation effect was evident in the extender, the moment it comes in contact with semen $(0 \mathrm{~h})$ and thereafter. The addition of $2 \%$ honey was associated with the highest motility rate at 1,2 and $4 \mathrm{~h}$ post-chilling. Fructose is the main natural energy source for buffalo spermatozoa in the seminal plasma for metabolic processes (Sansone et al., 2000). Honey is a mixture of sugars (fructose $\sim 38.5 \%$ and glucose $\sim 31.0 \%$ ) and other compounds (Silva et al., 2016). This may signify the appropriateness of honey to be used as an energy source in semen extenders for buffaloes. Therefore, it may be able to protect sperm during cryopreservation, as well as enhances sperm motility parameters during chilling. Olayemi et al. (2011) designated that honey supplementation in egg yolk based extender sustained buck spermatozoa motility for up to $6 \mathrm{~h}$ at $5^{\circ} \mathrm{C}$, and its effect depends on the proportion of honey to egg yolk in extender. El-Nattat et al. (2016) ascertained honey (at rate of 1\%) significance on preserving cattle bull sperm motility after 7 days of cooled with Tris-citrate extender.

The livability of cooled extended buffalo spermatozoa displayed a significant difference at $4 \mathrm{~h}(\mathrm{P}$ $<0.05$ ) after cooling. At $1 \mathrm{~h}$, spermatozoa livability was higher for milk-honey $0.5 \%$. At 2 and 4 h, an improved livability was observed with milk-honey $1.0 \%$. Similarly, Jerez-Ebensperger et al. (2015) established that the addition of honey and garlic reduces sperm deterioration when stored at $4^{\circ} \mathrm{C}$. Natural honey contains not only sugars (glucose, fructose and sucrose), but also vitamins and amino acids which accused its impact on livability of spermatozoa (Bamba et al., 1968). In vivo studies showed that supplementation of honey at rate of 5\% increased sorbitol dehydrogenase (converts sorbitol into fructose) by $31 \%$ and reduced the lactate dehydrogenase (metabolize via the glycolytic pathway in sperm to make ATP) by $48 \%$ (Abdul-Ghani et al., 2008). An improvement of sperm livability was noticed in buck semen extended with honey egg-yolk based extenders maintained at $4^{\circ} \mathrm{C}$ for $6 \mathrm{~h}$. This effect depended on the level of honey incorporated (Olayemi et al., 2011). Also, the survival of stallion spermatozoa stored at $0^{\circ}$ to $+6^{\circ} \mathrm{C}$ was greatest in the $10 \%$ solution of natural honey and better in 6-14\% solutions than in lower or higher solutions (Pecnikov and Skatkin, 1955 cited by Sharma, 1962).

Regarding the influence of honey incorporation in extenders on sperm morphology, current results indicated that the post-cooling spermatozoa normality was higher in extenders supplemented with honey. A remarkable correlation was found between total phenolic content and antiradical activities of honey (Beretta et al., 2005). Phenolic compounds may protect against oxidative stress induced by temperature alternation by neutralizing reactive oxidants through its electron- or hydrogen-liberation capacity, which would otherwise oxidize cellular constituents such as lipid, protein and nucleic acid (Moskaug et al., 2005). Addition of honey into Tris-extender at $2.5 \%$ enhanced semen quality by minimizing the percentage of sperm cells with abnormal morphology (Yimer et al., 2015).

Assessment of frozen semen activity herein verified that the post-thawing motility steadily increased with increasing the honey levels. What is more, the viability index of buffalo spermatozoa was significantly higher with milk supplemented with honey $(2.0-4.0 \%)$. Milk and milk-based extenders are branded to be practical and effective in protecting spermatozoa of many species (Batellier et al., 2001). Cryopreservation is known to cause damaging effects to spermatozoa during the freezing thawing process (Watson, 2000) through its eminent effect on plasma and mitochondria membranes and in the worst circumstance, the nucleus (Blesbois, 2007). The damage to membranes has consequences on viability and different metabolic elements such as adenosine triphosphate (ATP) concentration in spermatozoa (Andrabi, 2009). Normally honey exists below its melting point, so at very low temperatures of freezing, honey will not solidify, instead, its viscosity increases and it condenses. Nevertheless, it continues to flow at very slow rates. Below -42 and $-51^{\circ} \mathrm{C}$, honeys go through a glassy status 
and become non-crystalline solid (Kántor et al., 1999). Moreover, honey contains many biologically active compounds which impeding DNA damage due to free radicals (Moskaug et al., 2005). Addition of $10 \%$ honey solution to semen extender improved the sperm motility of frozen semen of Egyptian local breeds of cattle (ElSheshtawy et al., 2014). Tris plus $2.5 \%$ honey improved post-cryopreservation semen quality, while the use of honey at concentrations of 5 and $10 \%$ significantly lower semen quality following cryopreservation in cow bulls (Yimer et al., 2015). Addition of 2-5\% of honey solution to Tris-extender enhanced the sperm motility of buffalo bull semen (El-Nattat et al., 2016).

Buffalo spermatozoa membrane intactness was higher in milk-honey (1\%) at post-equilibration and in milk-honey $(2 \%)$ at post-thawing conditions. Addition of honey solution in a concentration $0.5 / 4.5 \mathrm{ml}$ (ElSheshtawy et al., 2014) and 1.5/3.5 ml (El-Nattat et al., 2016) significantly improved the rate of intact sperm membranes of cattle and buffalo bulls, respectively. These results could be related to the strong antioxidant property of honey which encloses a combination of sugars, proteins, enzymes, organic acids, vitamins, phenolic acids and flavonoids (Silva et al., 2016).

Honey supplemented in buffalo bull extenders induced a substantial improvement on the early cleavage divisions in vitro (especially milk-honey $2.0 \%$ ). These results are in agreement with former studies indicated that the incorporation of honey solution $(0.5 / 4.5 \mathrm{cc})$ in sperm extender improved the conception rate in cows (El-Sheshtawy et al., 2014).

In conclusion, incorporation of honey in skim milk extenders is beneficial for improving of chilled and frozen semen characteristics of Egyptian buffaloes as well as improves its fertilizing capacity as indicated by in vitro fertilization rate.

\section{References}

Abdul-Ghani AS, Dabdoub N, Muhammad R, Abdul-Ghani R, Qazzaz M. 2008. Effect of Palestinian honey on spermatogenesis in rats. J Med Food, 11:799802.

Aboagla EM, Terada T. 2003. Trehalose-enhanced fluidity of the goat sperm membrane and its protection during freezing. Biol Reprod, 69:1245-1250.

Akhter S. 2006. Effect of milk based extenders containing different antibiotics on sperm motility, longevity, morphology, plasma membrane integrity, in vivo fertility and bacterial control of liquid semen from buffalo bulls. Rawalpindi, Pakistan: University of Arid Agriculture. Doctoral Thesis.

Akhter S, Ansari MS, Andrabi SM, Ullah N, Qayyum M. 2008. Effect of antibiotics in extender on bacterial and spermatozoal quality of cooled buffalo (Bubalus bubalis) bull semen. Reprod Domest Anim, 43:272-278.

Amer H, Mansour H, El-Sayed A, Swelum A. 2008. Influence of filtration or centrifugation of semen diluent on the viability of chilled buffalo-bull semen. Stočarstvo, 62:351-366.

Andrabi SM. 2009. Factors affecting the quality of cryopreserved buffalo (Bubalus bubalis) bull spermatozoa. Reprod Domest Anim, 44:552-569.

Aoyagi Y, Fukui Y, Iwazumi Y, Urakawa M, Ono H. 1990. Effects of culture systems on development of in vitro fertilized bovine ova into blastocysts. Theriogenology, 34:749-759.

Bamba K, Kojima Y, Iida I. 1968. Studies on deepfreezing of boar semen. V. The effect of honey-yolk diluent on the livability of frozen boar spermatozoa. Nihon Chikusan Gakkaiho, 39:415-421.

Bang H, Davidian M. 2010. Experimental statistics for biological sciences. Methods Mol Biol, 620:3-104.

Batellier F, Vidament M, Fauquant J, Duchamp G, Arnaud G, Yvon JM, Magistrini M. 2001. Advances in cooled semen technology. Anim Reprod Sci, 68:181190.

Beretta G, Granata P, Ferrero M, Orioli M, Maffei Facino R. 2005. Standardization of antioxidant properties of honey by a combination of spectrophotometric/fluorimetric assays and chemometrics. Anal Chim Acta, 533:185-191.

Blesbois E. 2007. Current status in avian semen cryopreservation. World's Poult Sci J, 63:213-222.

Brackett BG, Oliphant G. 1975. Capacitation of rabbit spermatozoa in vitro. Biol Reprod, 12:260-274.

Bustamante Filho IC, Pederlozzi CD, Sgaravatti AM, Gregory RM, Dutra Filho CS, Jobim MIM, Mattos RC. 2009. Skim Milk-egg based semen extender compensates for non-enzymatic antioxidant activity loss during equine semen cryopreservation. Anim Reprod, 6:392-399.

Chenoweth PJ. 2002. Semen quality assessment. In: Proceedings, The Applied Reproductive Strategies in Beef Cattle Workshop, 2002, Manhattan, KS. Manhattan, KS: Kansas State University. pp. 247-254.

El-Nattat WS, El-Sheshtawy RI, El-Batawy KA, Shahba MI, EISeadawy IE. 2016. Preservability of buffalo bull semen in tris-citrate extender enriched with bee's honey. J Innov Pharm Biol Sci, 3:180-185.

El-Sheshtawy RI, El-Nattat WS, Sabra HA, Ali AH. 2014. Effect of honey solution on semen preservability of local breeds of cattle bulls. World Appl Sci J, 32:2076-2078

Gadea J. 2003. Review: semen extenders used in the artificial insemination of swine. Span J Agric Res, 1:1727.

Iritani A, Niwa K. 1977. Capacitation of bull spermatozoa and fertilization in vitro of cattle follicular oocytes matured in culture. J Reprod Fertil, 50:119-121. Iritani A, Kasai M, Niwa K, Song HB. 1984. Fertilization in vitro of cattle follicular oocytes with ejaculated spermatozoa capacitated in a chemically defined medium. J Reprod Fertil, 70:487-492.

Jerez R, González N, Olaciregui M, LuñoV, de Blas I, Gil L. 2016. Use of soy milk combined with different cryoprotectants for the ram semen cryopreservation. Small Rumin Res, 134:34-38.

Jerez-Ebensperger R, Gil L, Gonzales N, De Blas I. 2015. The combined use of honey, garlic (Allium sativum l.) and skimmed milk as an extender for chilling 
sheep semen. Cryo Letters, 36:243-251.

Kántor Z, Pitsi G, Thoen J. 1999. Glass transition temperature of honey as a function of water content as determined by differential scanning calorimetry. J Agric Food Chem, 47:2327-2330.

Mahmoud KGM. 2001. Cytogenetic studies on in-vitro fertilization in buffaloes. Giza: Faculty of Veterinary Medicine, Cairo University. PhD Thesis.

Moskaug JO, Carlsen H, Myhrstad MC, Blomhoff R. 2005. Polyphenols and glutathione synthesis regulation. Am J Clin Nutr, 81:277s-283s.

Niwa K, Ohgoda O. 1988. Synergistic effect of caffeine and heparin on in-vitro fertilization of cattle oocytes matured in culture. Theriogenology, 30:733-741.

Olayemi FO, Adeniji DA, Oyeyemi MO. 2011. Evaluation of sperm motility and viability in honey included egg yolk based extender. Global Vet, 7:19-21.

Salisbury GW, VanDemark NL, Lodge JR. 1978. Extenders and extension of unfrozen semen. In: Salisbury GW (Ed.). Physiology of Reproduction and Artificial Insemination of Cattle. San Francisco, CA: W.H. Freeman. pp. 442-493.
Sansone G, Nastri MJ, Fabbrocini A. 2000. Storage of buffalo (Bubalus bubalis) semen. Anim Reprod Sci, 62:55-76.

Sharma UD (Ed.). 1962. In Vitro Preservation of Sperms. New Delhi: Indian Council of Agricultural Research. JCAR Review Series No. 35.58 pp.

Avaliable on:

http://krishikosh.egranth.ac.in/bitstream/1/2035693/1/IV RI\%20B\%20574.pdf.

Silva PM, Gauche C, Gonzaga LV, Costa ACO, Fett

R. 2016. Honey: chemical composition, stability and authenticity. Food Chem, 196:309-323.

Warriach HM, Chohan KR. 2004. Thickness of cumulus cell layer is a significant factor in meiotic competence of buffalo oocytes. J Vet Sci, 5:247-251.

Watson PF. 2000. The causes of reduced fertility with cryopreserved semen. Anim Reprod Sci, 60/61:481-492.

Yimer N, Muhammad N, Sarsaifi K, Rosnina Y, Wahid H, Khumran AM, Kaka A. 2015. Effect of honey supplementation into Tris extender on cryopreservation of bull spermatozoa. Mal J AnimSci, 18:47-54. 